\title{
Tumor Necrosis Factor $\alpha$ Stimulates Her-2 Cleavage by Activated Caspase-8
}

\author{
Xiaojun Li Yang Zhao Yunfeng Zhang Ning Du Hong Ren \\ Department of Oncosurgery, First Affiliated Hospital of Medical College of Xi'an Jiao Tong University, \\ Xi'an
}

\author{
Key Words \\ Caspase-8 $\cdot$ TNF- $\alpha \cdot$ Her-2
}

\begin{abstract}
Background/Aim: Her-2 over-expression has been correlated with a poor prognosis in patients with breast cancer. Now, we explored the effect of TNF- $\alpha$ treatment and/or NFKB activation on Her-2 expression in MCF-7 breast adenocarcinoma cells. Methods: Stably transfected MCF-7 cell lines with pcDNA3.0, IKB $\alpha$ MT, c-FLIP/control shRNA were established by FuGENE with the supplementation of G418 $(500 \mu \mathrm{g} / \mathrm{ml})$. Western blot and Real-time PCR were applied to assess the expression levels of protein and mRNA of target gene. In addition, caspase-8 activity was evaluated by the incubation with a caspase- 8 fluorogenic substrate, Ac-IEPD-AMC using a spectrofluorometer. Results: It was uncovered that Her-2 was a new substrate for caspase8 and that tumor necrosis factor $\alpha$ (TNF- $\alpha$ ) stimulation resulted in a caspase-8-dependent Her-2 cleavage in MCF-7 breast adenocarcinoma cells defective for nuclear factor $K B$ (NFkB) activation. We demonstrated that the antiapoptotic transcription factor NFKB counteracted this cleavage through the induction of caspase-8 inhibitor, C-FLIP. Conclusion: we propose a novel mechanism in which NFKB functions as a new antiapoptotic factor by counteracting TNF- $\alpha$-triggered Her-2 cleavage.
\end{abstract}

Copyright $@ 2012$ S. Karger AG, Basel

\section{Introduction}

Tumor necrosis factor $\alpha$ (TNF- $\alpha$ ) can regulate proapoptotic and antiapoptotic signaling pathways through interaction with two receptors, TNF receptor 1 (TNF-R1) and TNF receptor 2 (TNF-R2) [1]. Following TNF- $\alpha$ triggering, TNF receptor is trimerized, and subsequently, 
various signaling proteins were recruited to the receptor cytoplasmic domains [1-3]. Activation of TNF-R2 yields an antiapoptotic and proinflammatory cascade [4], while TNF$\mathrm{R} 1$ trimerization results in apoptosis through the recruitment and activation of caspase-8 as blocked the activation of the anti-apoptotic and proinflammatory transcription factor, nuclear factor $\kappa \mathrm{B}(\mathrm{NF \kappa B})$ [4-6]. Furthermore, $N F \kappa B$ target genes, including caspase inhibitors such as c-IAPs, XIAP, and c-FLIP; Bcl-2 family members; and other proteins like A20, counteract TNF- $\alpha$-induced apoptosis $[7,8]$.

Human cancers are defined as an upregulated proliferation and a downregulated apoptosis. Among the proteins implicated in this dysregulation, Her-2 functions as a pivotal role in breast cancer cells [9-11]. Her-2 oncogene induces the expression of a transmembrane receptor protein structurally similar to epidermal growth factor receptor (EGFR). It was reported that Her-2 was over-expressed in approximately one-third of primary breast cancer, which was correlated with a poor prognosis and decreased overall or disease-free survival [9-11]. Her-2 over-expression is potential to enhance proliferation, metastasis, and prosurvival signals in breast cancer cell lines and to induce resistance to hormonal therapy $[12,13]$. Moreover, anti-Her-2 monoantibody, trastuzumab has clinical activity either alone or combined with chemotherapy in Her-2-positive breast cancers [12]. Because association between Her-2 over-expression and NFKB currently is elusive, we explored the effect of TNF$\alpha$ treatment and/or NFKB activation on Her-2 expression in MCF-7 breast adenocarcinoma cells. Our outcomes showed that TNF- $\alpha$ treatment led to intracellular Her-2 cleavage via a caspase-8-dependent signaling pathway in MCF-7 cells defective for NFKB activation. Therefore, our results provided the evidence to refer Her-2 as a brand-new caspase- 8 substrate and demonstrated that NFKB can remarkably inhibit Her-2 degradation, that could be a novel mechanism for NFKB antiapoptotic role.

\section{Materials and Methods}

\section{Reagents}

Human recombinant TNF- $\alpha$ and actinomycin D were purchased from Sigma (St. Louis, U.S.A). Recombinant caspase- 8 and caspase- 8 inhibitors were purchased from Calbiochem (La Jolla, CA).

\section{Cell culture and transfection}

MCF-7 breast adenocarcinoma cells ( generously supplied by Dr. Chen Huang, Medical College of Xi'an Jiao Tong University, Xi'an, Shaanxi Province, P.R. China) were cultured and passaged in RPMI 1640 medium supplemented with $10 \%$ stripped fetal bovine serum, $1 \%$ L-glutamine (200 mM), penicillin (100 IU), and streptomycin $(100 \mu \mathrm{g} / \mathrm{ml})$. For the stably transfected cell lines (pcDNA3.0 and IкB $\alpha$ MT), culture medium

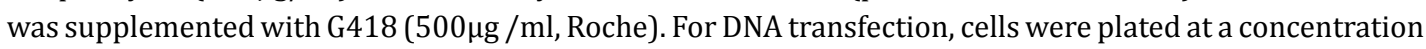
of $7 \times 10^{5}$ cells per $35-\mathrm{mm}$-diameter culture dish and transfected $24 \mathrm{~h}$ later with FuGENE (Sigma, U.S.A), according to the protocol provided by the manufacturer (Roche, Switzerland).

\section{Protein extraction and Western blot analysis}

Whole cell extracts were obtained by resuspending the PBS-washed cellular pellets in 1\% SDS. Then, lysates were boiled for $10 \mathrm{~min}$, and protein amounts were quantified with Micro BCA Protein Assay reagent (Pierce, Rockford, IL) using a BSA standard solution curve as the manufacturer's protocol. Protein extracts were separated on SDS-PAGE gels and blotted onto a polyvinylidenediflouride (PVDF) membrane (Millipore, Bedford, MA).The membranes then were blocked in Tris-buffered saline/Tween 20\% buffer plus $5 \%$ nonfat dry milk, incubated for $2 \mathrm{~h}$ with first antibody, washed with Tris-buffered saline/Tween 20\%, and incubated for $1 \mathrm{~h}$ with second horseradish peroxidase-conjugated antibody (DAKO, Glostrup, Denmark). The reaction was revealed with the enhanced chemoluminescence detection method (ECL kit; Amersham Pharmacia Biotech, Piscataway, NJ). 
Fig. 1. Tumor necrosis factor $\alpha$ (TNF$\alpha)$-mediated Her-2 degradation in nuclear factor $\kappa \mathrm{B}(\mathrm{NF} \kappa \mathrm{B})$-defective MCF-7 cells. pcDNA3.0 or I $\kappa \mathrm{B} \alpha \mathrm{MT}$ MCF-7 cells were treated with TNF$\alpha(100$ units $/ \mathrm{ml})$ as indicated. $10 \mu \mathrm{g}$ of total protein extract was analyzed by Western blot with a specific antiHer-2 COOH-terminal antibody. A nonspecific band (NS) was also shown as loading control.

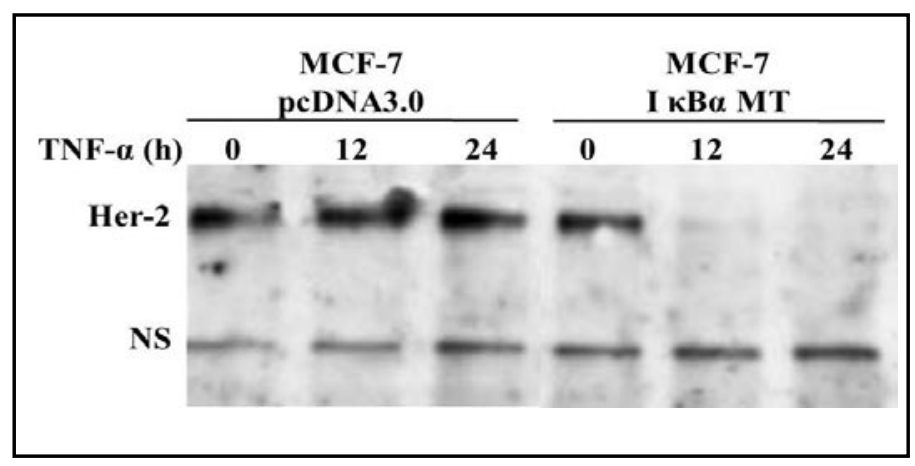

The antibodies were used for Western blot analysis: rabbit polyclonal anti-Her-2 (ab-2428), mouse monoclonal anti-actin (ab-3280), rabbit polyclonal anti-XIAP (ab-21278), rabbit polyclonal anti-c-FLIP (ab8421), rabbit polyclonal anti-c-IAP-1 (ab-2399), and anti-c-IAP-2 (ab-23423) were obtained from Abcam (U.S.A).

Real-time quantitative PCR

Total RNA was extracted using RNeasy columns from Qiagen (Valencia, Spain) according to the manufacturer's recommendations. After DNase treatment, RNAs were eluted and quantified using a spectrophotometer. $1.0 \mu \mathrm{g}$ of RNA was reverse transcribed using the first-strand cDNA synthesis kit for reverse transcription-PCR (Roche).The quantitative PCR reaction system involved $2.0 \mu \mathrm{l}$ of $20 \times$ diluted cDNAs, $2.0 \mu \mathrm{l}$ of $10 \times$ SYBR Green PCR mix buffer, $1.6 \mu \mathrm{l}$ of $25 \mathrm{mM} \mathrm{MgCl}_{2}$ and $7.0 \mu \mathrm{M}$ of each primer. The number of cycles was selected to allow linear amplification of the cDNAs. For quantitative PCR, GAPDH was selected as control. Quantification was performed with the Light Cycler PCR (Eppendorf). The primer sequences were as follows: GAPDH, 5'-ATGGGGAAGGTGAAGGTGGTC-3' and 5'-TGATGGCATGGACTGTGG-3'; and Her-2, 5'-AGACGAAGCATACGTGA-3' and 5'-GTACGAGCCGCACATC-3'.

\section{Caspase-8 activity}

To evaluate caspase- 8 activity, pcDNA3 MCF-7 cells and I $\kappa$ B $\alpha$ MT cells were stimulated with TNF- $\alpha$. Cell lysates then were incubated for $3 \mathrm{~h}$ at $37^{\circ} \mathrm{C}$ with a caspase- 8 fluorogenic substrate, Ac-IEPD-AMC (Sigma, U.S.A). Subsequently, the fluorescence of generated cleaved product was assessed using a spectrofluorometer (380 $\mathrm{nm}$ and $460 \mathrm{~nm}$ ). The experimental procedure followed the manufacturer's recommendations.

FLIP antisense experiments

c-FLIP shRNA, 5'-ACTTGTCCCTGCTCCTTGAA-3'; control shRNA, 5'-ATCACGTATCGTCGCTTCTC-3' bearing phosphorothioate linkages were delivered into cells by FuGENE (Roche, U.S.A) at a final concentration of $10 \mu \mathrm{M}$ for $8 \mathrm{~h}$ before TNF- $\alpha$ treatment.

\section{Results}

TNF- $\alpha$-induced Her-2 degradation in NFKB-defective cells

To invetigate the effects of TNF- $\alpha$ and NFKB on Her-2 expression, we used MCF-7 breast adenocarcinoma cells stably transfected with either an empty vector pcDNA3.0 (control cells)

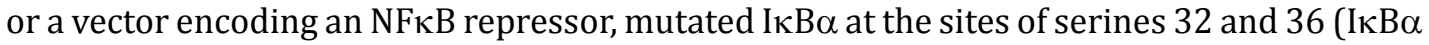
MT or MT cells), that inhibited NFKB activity and in turn led to enhanced apoptotic response to TNF- $\alpha$. Both cell lines were stimulated with TNF- $\alpha$ for $24 \mathrm{~h}$. Then, Her-2 expression was investigated by Western blot. An obvious decrease in Her-2 expression was detectable in MCF-7 cells with the mutated form of IкB $\alpha$ (Fig. 1). To further explore the transcriptional influence on decreased Her-2 protein, MCF-7 cells with pcDNA 3.0 or IкB $\alpha$ MT was stimulated with TNF- $\alpha$ for $24 \mathrm{~h}$. Then, the transcriptional level of Her- 2 was tested by quantitative realtime PCR using Her-2-specific primers and GAPDH gene as control. No significant differences 
Fig. 2. Her-2 mRNA synthesis and stability. A, pcDNA3.0 or I $\mathrm{B} \alpha$ MT MCF-7 cells were stimulated by tumor necrosis factor $\alpha$ (TNF$\alpha, 100$ units $/ \mathrm{ml}$ ) as indicated. Quantitative real-time PCR was performed using Her-2specific oligonucleotides and glyceraldehyde3-phosphate dehydrogenase (GAPDH) as control. B, control or MT cells were treated with actinomycin D (5 $\mu \mathrm{g} / \mathrm{ml})$ as indicated. Quantitative real-time PCR was performed as in $2 \mathrm{~A}$.

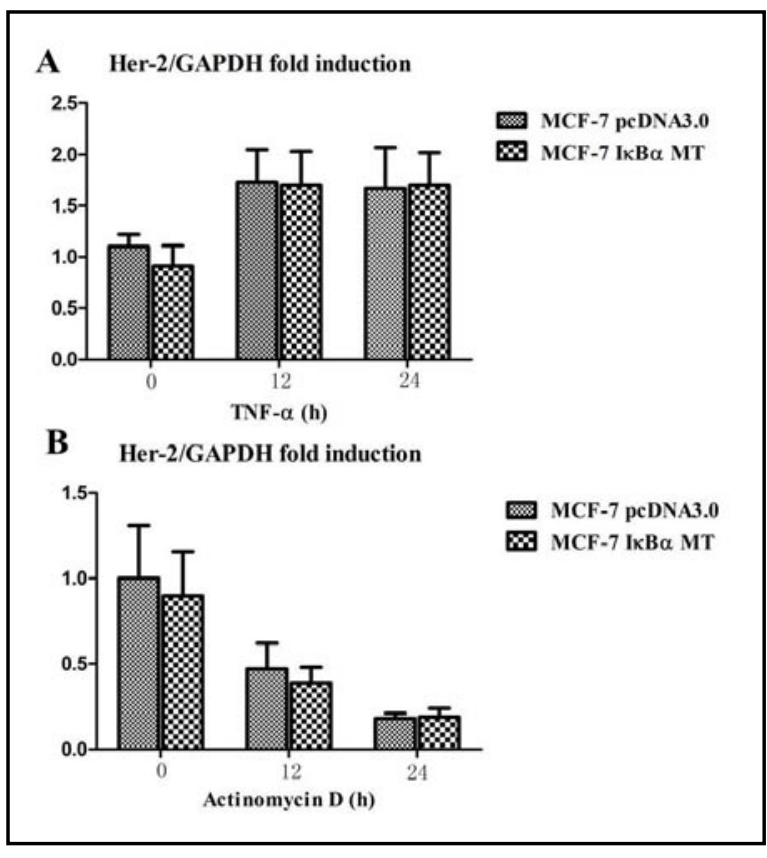

Fig. 3. Her-2 protein stability. I $\mathrm{B} \alpha \mathrm{MT}$ cellswereincubatedwith or without Phenylmethylsulfonyl fluoride (PMSF, $10 \mu \mathrm{g} / \mathrm{ml}$ ) for 1 $\mathrm{h}$ before tumor necrosis factor $\alpha$ (TNF- $\alpha, 100$ units $/ \mathrm{ml}$ ) time course stimulation. $10 \mu \mathrm{g}$ of total cellular extract was subjected to anti-Her-2 Western blot analysis.

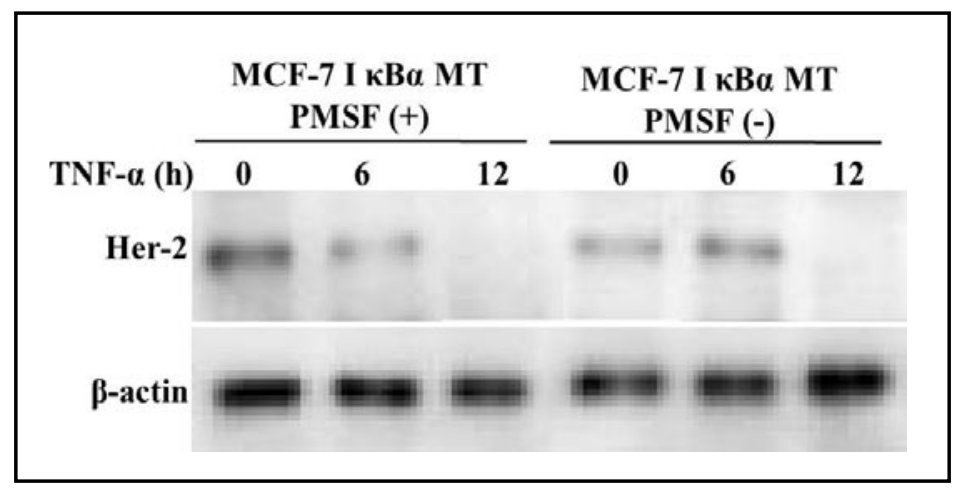

in Her-2 mRNA level were observed after both cell lines were stimulated by TNF- $\alpha$ (Fig. 2A).

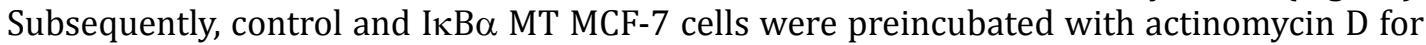
$1 \mathrm{~h}$ to block RNA neosynthesis before a TNF- $\alpha$ stimulation. The degradation of Her-2 mRNA was identical in both cell lines (Fig. 2B). These outcomes showed that TNF- $\alpha$-mediated Her2 downregulation was not the consequence of decreased RNA transcription.

\section{Her-2 cleavage by TNF- $\alpha$-activated caspase-8 in $N F \kappa B$-defective cells}

In the light of the outcomes mentioned above, we postulated that downregulated Her2 in response to TNF- $\alpha$ treatment might be a consequence of protease activation. To test such a hypothesis, we preincubated cells with protease inhibitors and tested their ability to counteract TNF- $\alpha$-mediated Her- 2 decay. Phenylmethylsulfonyl fluoride (PMSF, a serine protease inhibitor) did not prevent Her-2 decay in response to TNF- $\alpha$ in the cells over-

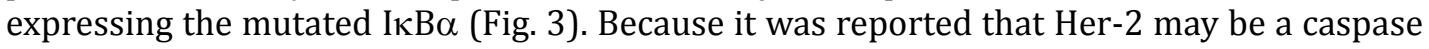
substrate, it was of interests to investigate this signaling pathway in our study. It was observed

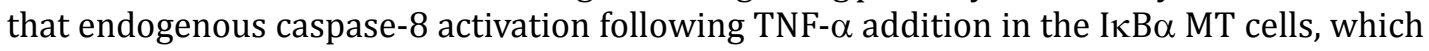
was perfectly paralleled with Her-2 decay (Figs. 4A and B). Moreover, a specific caspase-8 inhibitor, z-IETD-fmk, was used to block TNF- $\alpha$-induced Her-2 degradation in MCF-7 cells with IкB $\alpha$ MT (Fig. 5). Her-2 cleavage presented and was inhibited by the specific caspase-8 inhibitor. Taken together, these data indicated that caspase-8 was responsible for the TNF$\alpha$-induced Her-2 degradation in the NFkB-deficient cells. 
Fig. 4. Caspase-8 cleavage and activation in response to tumor necrosis factor $\alpha$ (TNF- $\alpha$ ). A, pcDNA3.0 MCF-7 cells and I $\mathrm{BB} \alpha$ MT MCF-7 cells were stimulated with TNF- $\alpha$. Proteolysis of caspase-8 in total cellular extract $(10 \mu \mathrm{g})$ was assessed by Western blot analysis. Caspase-8 proform was indicated by an arrow, and asterisks showed the cleaved fragments. B, pcDNA3.0 and $\mathrm{I} \kappa \mathrm{B} \alpha$ MT MCF-7 cells were stimulated with TNF- $\alpha$ as indicated. Cellular extracts were incubated with a fluorogenic caspase-8 substrate. The fluorescence of generated cleaved product was assessed with a spectrofluorometer.
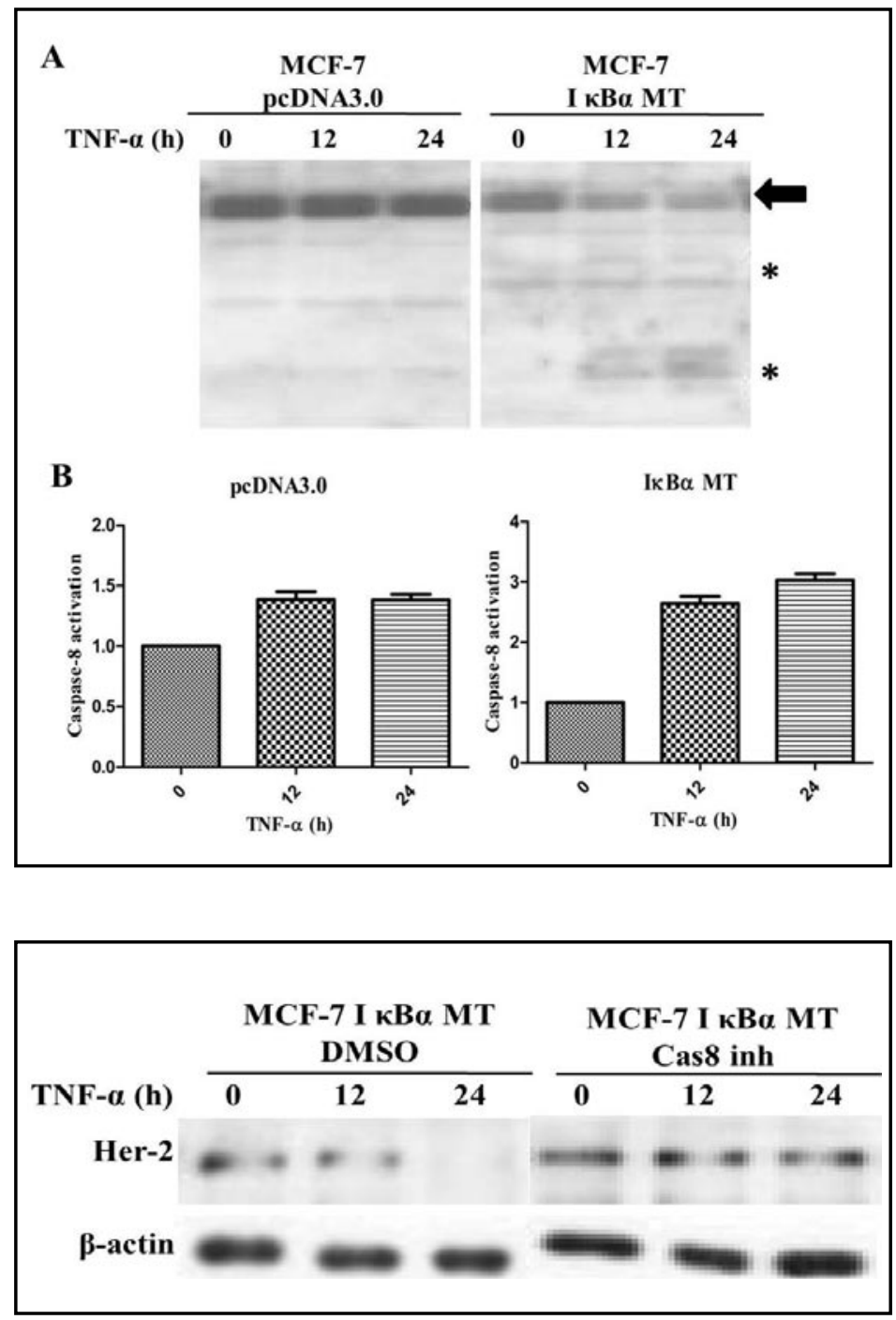

Fig. 5. Her-2 cleavage by caspase8. I $\kappa \mathrm{B} \alpha$ MT MCF-7 cells were stimulated with tumor necrosis factor $\alpha$ (TNF- $\alpha, 100$ units $/ \mathrm{ml}$ ) as indicated in the absence (left) or presence (right) of the caspase-8 inhibitor $(20 \mu \mathrm{M})$. Western blot analysis was carried out with 10$\mu \mathrm{g}$ total extract. Proteins were tested with anti-Her-2, and antiactin antibodies as indicated.

\section{Inhibition of caspase-8-mediated Her-2 cleavage by $N F \kappa B$-regulated c-FLIP}

Our report showed that caspase-8-induced Her-2 decay only occurred in the MCF-7 cells with the inhibition of NFKB activation or synthesis. Furthermore, we identified NFKBregulated genes in control and MT cells treated with TNF- $\alpha$ after total cellular lysates were analyzed by Western blot analysis revealed with the specific antibodies. Accordingly, c-IAP-

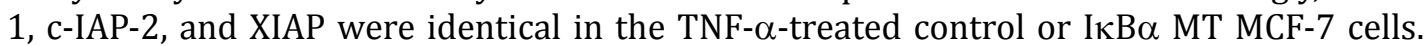
However, c-FLIP-L was increased remarkably in the TNF- $\alpha$-stimulated control cells as compared with MT cells (Fig. 6). Because c-FLIP-L is a well-known caspase-8 inhibitor and an $\mathrm{NF} \kappa \mathrm{B}$ target gene $[14,15]$. Therefore, we further investigated whether modulation of c-FLIP$\mathrm{L}$ affected Her-2 cleavage. Specific shRNA targeting c-flip mRNA efficiently attenuated c-FLIPL expression in MCF-7 control cells, whereas control shRNA did not (Fig. 7). The inhibition of c-FLIP-L expression in control MCF-7 cells was associated with TNF- $\alpha$-induced Her-2 degradation (Fig. 7). In addition, the opposite experiment was performed by re-introducing c-FLIP-L exogenous transient expression in MT cells. Ectopic c-FLIP-L expression partially inhibited TNF- $\alpha$-mediated Her-2 cleavage (Fig. 8). 
Fig. 6. Expression of nuclear factor $\kappa \mathrm{B} \quad(\mathrm{NF} \kappa \mathrm{B})$-regulated genes. pcDNA3.0 and $\mathrm{I} \kappa \mathrm{B} \alpha \mathrm{MT}$ MCF-7 cells were stimulated with tumor necrosis factor $\alpha$ (TNF$\alpha, 100$ units $/ \mathrm{ml}$ ) for $24 \mathrm{~h}$. Total extracts $(10 \mu \mathrm{g})$ were analyzed by Western blot with anti-c-IAP1, anti-c-IAP-2, anti-XIAP, anti-cFLIP-L, and anti-actin antibodies, respectively.

Fig. 7. Increased Her-2 cleavage by inhibition of c-FLIP. pcDNA3.0 MCF-7 cells were transfected with c-FLIP-L shRNA or control shRNA. After stable transfection, cells were untreated or were stimulated with tumor necrosis factor $\alpha$ (TNF- $\alpha, 100$ units/ml) for 24 h. Total extracts $(10 \mu \mathrm{g})$ were evaluated by Western blot with anti-Her-2, anti-c-FLIP-L, and antiactin antibodies, respectively.

Fig. 8. Inhibition of Her-2 cleavage by c-FLIP expression. I $\kappa \mathrm{B} \alpha \mathrm{MT}$ MCF-7 cells were transfected with pcDNA3.0 or c-FLIP-L expression vectors. After stable transfection, cells were stimulated with TNF- $\alpha \quad(100 \quad$ units $/ \mathrm{ml})$ as indicated. Western blot analysis was performed with total extracts (10 $\mu \mathrm{g})$ using anti-Her-2, anti-cFLIP-L, and anti-actin antibodies.
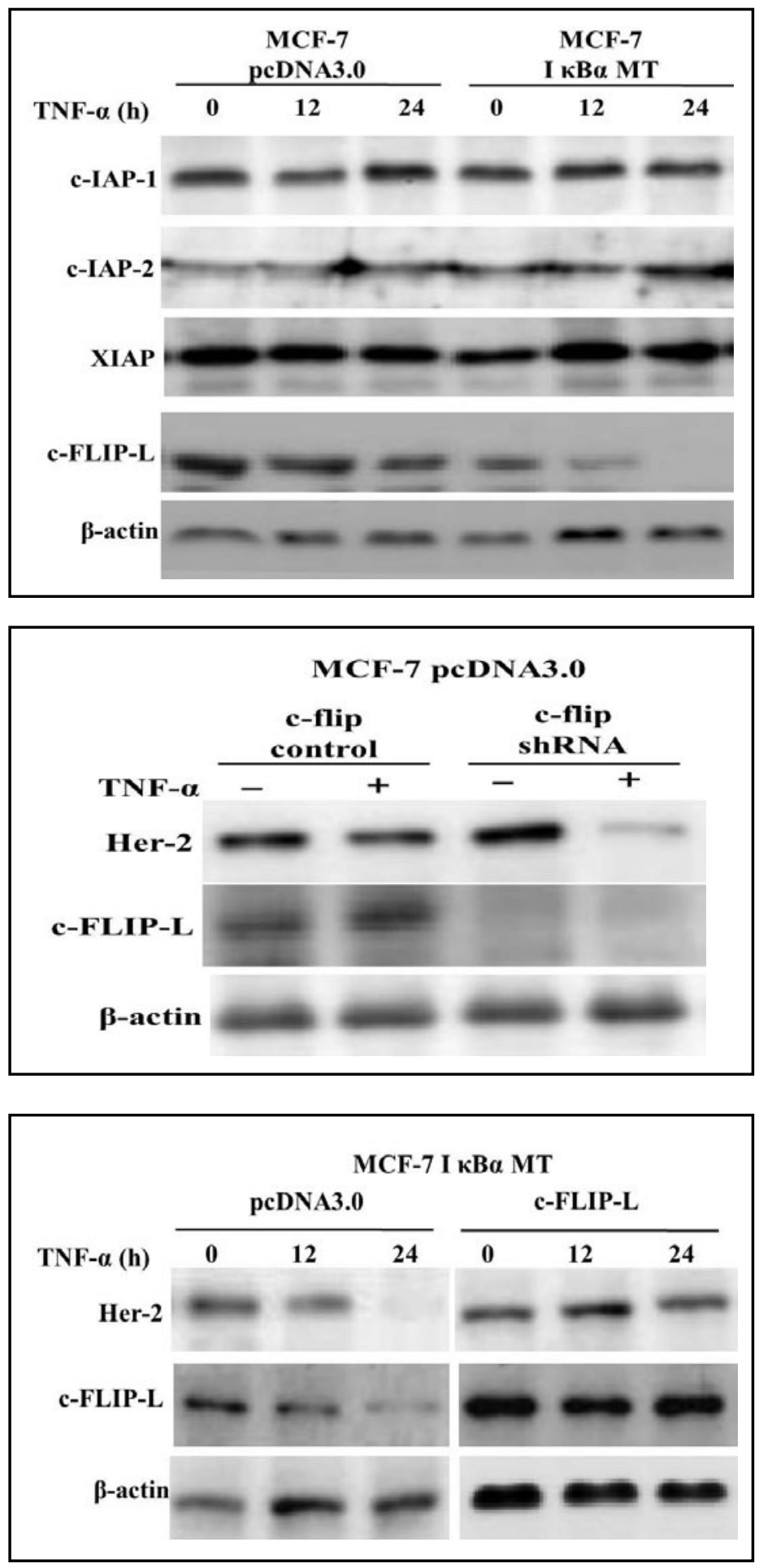

\section{Discussion}

The apoptosis depends on the activity of caspases family, a growing family of aspartylspecific cysteine proteases that are essential for the execution of apoptotic cascade by the cleavage of broad-spectrum substrates, including DNA repair molecule like PARP, focal 
adhesion kinase, oncoproteins such as Bcl-2, and signaling proteins [16-19]. Because caspases are responsible for the cell apoptotic cascade, identification of their cellular substrates is essential and provides new insights into downstream events involved in apoptosis signaling. Our outcomes clearly defined Her- 2 as a caspase- 8 substrate. It was of interest that Her- 2 molecule cleavage by activated caspase- 8 occurred after TNF- $\alpha$ treatment, implying that this cleavage might be involved in proapoptotic signaling progression.

It was previously demonstrated that TNF- $\alpha$ treatment led to a decrease in Her-2 mRNA synthesis and expression level of Her-2 protein [20,21]. We did not observe any effects of TNF- $\alpha$ on Her-2 transcription level. It was likely that these discrepancies resulted from the differences in the cell lines. However, it was the first time that we reported a caspasedependent cleavage of Her-2 following TNF- $\alpha$ treatment.

In breast cancer cells, it was poven that oncoprotein Her-2 was able to promote proliferative, metastatic, and prosurvival events and correlated with a poor prognosis [9, 22]. Furthermore, Her- 2 expression induced a resistance to chemoradiotherapy, and its inhibition by a specific monoclonal antibody, trastuzumab, yields the predominant clinical activity either alone or in combination with chemotherapy in the Her-2-positive breast cancers [23-26]. Moreover, it has been uncovered that Her-2 over-expression could induce resistance to TNF- $\alpha$ stimulation and that trastuzumab can restore the cytotoxic response $[20,21]$. Our results raised a hypothesis that caspase-8-mediated Her-2 cleavage following TNF- $\alpha$ treatment could take part in the cell apoptosis. Wild-type Her-2 over-expression by the transfection of the plasmid bearing wild-type Her-2 is potential to significantly inhibit TNF- $\alpha$-induced cell death, and a survival disadvantage was not displayed following the overexpression of an uncleavable Her-2, demonstrating that Her-2 cleavage leads to apoptosis.

Her-2-related signalings counteract cell apoptosis by inducing antiapoptotic pathways, such as Bcl-2 and Bcl-XL upregulation or by activating the Akt/NFKB prosurvival cascade [27-29]. NFKB is an extensively defined antiapoptotic factor, whose nuclear DNA binding is potently and rapidly induced by TNF- $\alpha$ treatment in almost all of the cancer cell lines [30,31]. Constitutive NFKB activation has been observed in a wide variety of cancers and associated with a resistance to apoptosis owing to its target genes encoding for antiapoptotic molecules $[30,31]$. In our study, TNF- $\alpha$ stimulation led to NFKB activation, and subsequent expression of one of its target genes, c-FLIP. c-FLIP is extensively defined as a caspase-8 inhibitor and therefore counteracts Her- 2 cleavage triggered by TNF- $\alpha$ stimulation. c-FLIP-mediated

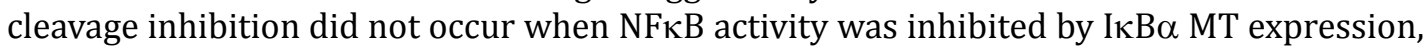
demonstrating that it required the integrity of the NFKB pathway. We demonstrated that Her2 cleavage might participate in TNF- $\alpha$-induced apoptosis, indicating that NFKB-dependent blockage of Her-2 cleavage was a novel mechanism for NFKB antiapoptotic role.

In conclusion, we provide evidence, for the first time, that caspase-8 cleaves Her- 2 protein in response to TNF- $\alpha$ stimulation, and we propose an original model in which NFkB exerts a new antiapoptotic function through c-FLIP-induced expression and subsequent inhibition of TNF- $\alpha$-triggered cleavage of Her-2. Therefore, this antiapoptotic mechanism underlines the opportunity to evaluate the NFKB activation status and the Her-2 expression level in breast cancer cells and opens new insights to develop combined anticancer therapies for Her-2overexpressing breast cancers. Because NFKB inhibitors currently are being evaluated as anticancer therapeutic agents, our results indicate a putative novel activity for these agents. Antibodies against Her-2 and NFKB inhibitors may be combined with chemotherapy or biological modifiers for the management of Her-2-overexpressing cancers.

\section{Grant Support}

Supported by national natural science foundation of China (NNSFC, No.30740022 and 30951128). 


\section{Cellular Physiology Cell Physiol Biochem 2012;30:889-897 and Biochemistry

\section{References}

1 Wang L, Du F, Wang X: Tnf-alpha induces two distinct caspase-8 activation pathways. Cell 2008;133:693703.

-2 Gentle IE, Wong WW, Evans JM, Bankovacki A, Cook WD, Khan NR, Nachbur U, Rickard J, Anderton H, Moulin M, Lluis JM, Moujalled DM, Silke J, Vaux DL: In tnf-stimulated cells, ripk1 promotes cell survival by stabilizing traf2 and ciap1, which limits induction of non-canonical nf-kappab and activation of caspase-8. J Biol Chem 2011;286:13282-13291.

-3 Wang S: The promise of cancer therapeutics targeting the tnf-related apoptosis-inducing ligand and trail receptor pathway. Oncogene 2008;27:6207-6215.

-4 Wajant H, Henkler F, Scheurich P: The tnf-receptor-associated factor family: Scaffold molecules for cytokine receptors, kinases and their regulators. Cell Signal 2001;13:389-400.

$>5$ Locksley RM, Killeen N, Lenardo MJ: The tnf and tnf receptor superfamilies: Integrating mammalian biology. Cell 2001;104:487-501.

6 Zhao Y, Li X, Sun X, Zhang Y, Ren H: Emt phenotype is induced by increased src kinase activity via srcmediated caspase-8 phosphorylation. Cellular physiology and biochemistry: international journal of experimental cellular physiology, biochemistry, and pharmacology 2012;29:341-352.

7 Cude K, Wang Y, Choi HJ, Hsuan SL, Zhang H, Wang CY, Xia Z: Regulation of the g2-m cell cycle progression by the erk5-nfkappab signaling pathway. The Journal of cell biology 2007;177:253-264.

8 Kreuz S, Siegmund D, Rumpf JJ, Samel D, Leverkus M, Janssen O, Hacker G, Dittrich-Breiholz O, Kracht M, Scheurich P, Wajant H: Nfkappab activation by fas is mediated through fadd, caspase-8, and rip and is inhibited by flip. The Journal of cell biology 2004;166:369-380.

-9 Zhang H, Ren G, Wang X, Zhao J, Yao H, Bai Y, Bo W: Her-2 gene amplification by fluorescence in situ hybridization (fish) compared with immunohistochemistry (ihc) in breast cancer: A study of 528 equivocal cases. Breast Cancer Res Treat 2012;134:743-749.

-10 Hojati Z, Orangi E: Her-2/neu gene amplification assessment in breast cancer patients in isfahan province by real time pcr, differential pcr and immunohistochemistry. Gene 2012;497:237-242.

-11 Sanpaolo P, Barbieri V, Pedicini P, Fusco V: Her-2 prognostic value in very early-stage breast cancer: A single-institution retrospective analysis. Med Oncol 2012;29:459-465.

12 Twombly R: Hints of future progress for her-2 breast cancer. J Natl Cancer I 2011;103:535-537.

13 Hayashi N, Iwamoto T, Gonzalez-Angulo AM, Ferrer-Lozano J, Lluch A, Niikura N, Bartholomeusz C, Nakamura S, Hortobagyi GN, Ueno NT: Prognostic impact of phosphorylated her-2 in her-2+ primary breast cancer. Oncologist 2011;16:956-965.

-14 Moujalled DM, Cook WD, Lluis JM, Khan NR, Ahmed AU, Callus BA, Vaux DL: In mouse embryonic fibroblasts, neither caspase-8 nor cellular flice-inhibitory protein (flip) is necessary for tnf to activate nfkappab, but caspase-8 is required for tnf to cause cell death, and induction of flip by nf-kappab is required to prevent it. Cell Death Differ 2012;19:808-815.

15 Pop C, Oberst A, Drag M, Van Raam BJ, Riedl SJ, Green DR, Salvesen GS: Flip(l) induces caspase 8 activity in the absence of interdomain caspase 8 cleavage and alters substrate specificity. The Biochemical journal 2011;433:447-457.

16 Dotto GP, Silke J: More than cell death: Caspases and caspase inhibitors on the move. Dev Cell 2004;7:2-3. Foster GR: Apoptotic cell death: The caspase-cleavage "gold rush". Lancet 2005;365:1293-1294.

-18 Riedl SJ, Shi Y: Molecular mechanisms of caspase regulation during apoptosis. Nat Rev Mol Cell Biol 2004;5:897-907.

19 Thorburn A: Death receptor-induced cell killing. Cell Signal 2004;16:139-144.

-20 Lyu MA, Kurzrock R, Rosenblum MG: The immunocytokine scfv23/tnf targeting her-2/neu induces synergistic cytotoxic effects with 5-fluorouracil in tnf-resistant pancreatic cancer cell lines. Biochem Pharmacol 2008;75:836-846.

21 Lyu MA, Rosenblum MG: The immunocytokine scfv23/tnf sensitizes her-2/neu-overexpressing skbr-3 cells to tumor necrosis factor (tnf) via up-regulation of tnf receptor-1. Mol Cancer Ther 2005;4:1205-1213.

22 De Mattos-Arruda L, Cortes J: Advances in first-line treatment for patients with her-2+ metastatic breast cancer. Oncologist 2012;17:631-644. 


\section{Cellular Physiology $\quad$ Cell Physiol Biochem 2012;30:889-897 and Biochemistry

-23 Baselga J, Bradbury I, Eidtmann H, Di Cosimo S, de Azambuja E, Aura C, Gomez H, Dinh P, Fauria K, Van Dooren V, Aktan G, Goldhirsch A, Chang TW, Horvath Z, Coccia-Portugal M, Domont J, Tseng LM, Kunz G, Sohn JH, Semiglazov V, Lerzo G, Palacova M, Probachai V, Pusztai L, Untch M, Gelber RD, Piccart-Gebhart M: Lapatinib with trastuzumab for her2-positive early breast cancer (neoaltto): A randomised, open-label, multicentre, phase 3 trial. Lancet 2012;379:633-640.

24 Collins I, Francis P, Mileshkin L: Adjuvant trastuzumab in her2-positive breast cancer. N Engl J Med 2012;366:664; author reply 664-666.

25 Leary AF, Hanna WM, van de Vijver MJ, Penault-Llorca F, Ruschoff J, Osamura RY, Bilous M, Dowsett M: Value and limitations of measuring her-2 extracellular domain in the serum of breast cancer patients. Journal of clinical oncology: official journal of the American Society of Clinical Oncology 2009;27:16941705.

26 Vanden Bempt I, Van Loo P, Drijkoningen M, Neven P, Smeets A, Christiaens MR, Paridaens R, De WolfPeeters C: Polysomy 17 in breast cancer: Clinicopathologic significance and impact on her- 2 testing. Journal of clinical oncology: official journal of the American Society of Clinical Oncology 2008;26:4869-4874.

-27 Siddiqa A, Long LM, Li L, Marciniak RA, Kazhdan I: Expression of her-2 in mcf-7 breast cancer cells modulates anti-apoptotic proteins survivin and bcl-2 via the extracellular signal-related kinase (erk) and phosphoinositide-3 kinase (pi3k) signalling pathways. BMC Cancer 2008;8:129.

28 Pianetti S, Arsura M, Romieu-Mourez R, Coffey RJ, Sonenshein GE: Her-2/neu overexpression induces nfkappab via a pi3-kinase/akt pathway involving calpain-mediated degradation of ikappab-alpha that can be inhibited by the tumor suppressor pten. Oncogene 2001;20:1287-1299.

29 Zhou BP, Hu MC, Miller SA, Yu Z, Xia W, Lin SY, Hung MC: Her-2/neu blocks tumor necrosis factor-induced apoptosis via the akt/nf-kappab pathway. J Biol Chem 2000;275:8027-8031.

-30 Shih VF, Tsui R, Caldwell A, Hoffmann A: A single nfkappab system for both canonical and non-canonical signaling. Cell Res 2011;21:86-102.

-31 Graham B, Gibson SB: The two faces of nfkappab in cell survival responses. Cell Cycle 2005;4:1342-1345. 